\title{
Bacterial Infections of the Central Nervous System
}

Roos, Karen L. MD, FAAN

\begin{abstract}
Bacterial infections of the central nervous system are a neurological emergency. Prompt recognition and treatment are not only essential to prevent mortality but also to decrease neurological sequelae. This chapter will focus on the two most common central nervous system bacterial infections, bacterial meningitis and spinal epidural abscess. The eradication of the pathogen with antimicrobial therapy is the easy part. It is the recognition of the disorder, the understanding of the diagnostic studies and their limitations, and the management of the neurological complications that requires the expertise of a neurologist.
\end{abstract}

\section{Introduction}

There are a number of bacterial infections of the central nervous system, including meningitis, brain abscess, cranial and spinal epidural abscess and subdural empyema and suppurative dural sinus thrombophlebitis, but this chapter will focus on the two central nervous system bacterial infections that neurologists encounter the most often and have a critical role in diagnosis, management and lifetime care. Those infections are bacterial meningitis and spinal epidural abscess.

\section{Meningitis}

For two centuries, the clinical presentation of bacterial meningitis was recognized as the classic triad of fever, headache and stiff neck. Then a number of years ago, papers began to appear in the literature challenging the classic triad, primarily over the lack of, or ability to detect, a stiff neck. This controversy was resolved by the recognition that the majority of patients with bacterial meningitis have fever (greater than or equal to $38.5^{\circ} \mathrm{C}$ ), and either headache, stiff neck or an altered level of consciousness. ${ }^{1-3}$ A symptom that is often present, but under recognized as a symptom of central nervous system (CNS) infection, is vomiting.

When bacterial meningitis is considered a possibility, blood cultures should be obtained and empiric antimicrobial and adjunctive therapy initiated. Empiric antimicrobial therapy is based on predisposing and associated conditions which predict the meningeal pathogen. Almost all recommended empiric antimicrobial regimens include a third-or fourth generation cephalosporin plus vancomycin. Ampicillin is added for coverage of Listeria monocytogenes where indicated (discussed below), and metronidazole when the predisposing conditions of otitis, sinusitis or mastoiditis are present. 4 Prior to or with the first dose of antibiotic therapy, dexamethasone $(0.15$ $\mathrm{mg} / \mathrm{kg}$ every six hours for 2-4 days) is initiated in patients with suspected pneumococcal, meningococcal or Haemophilus influenzae type b meningitis. ${ }^{5-7}$ Empiric therapy based on the 
predicted meningeal pathogen is listed in Table 1 and the recommended dose of antibiotic is listed in Table 2.

After treatment has been initiated, thoughtful consideration of etiological organism, diagnostic studies, differential diagnosis and treatment can be undertaken .

Table 1 Empiric antimicrobial therapy based on the predicted meningeal pathogen

\begin{tabular}{|c|c|c|}
\hline Predisposing condition & Bacterial pathogen & Antibiotic \\
\hline $\begin{array}{l}\text { Children and adults - } \\
\text { community acquired }\end{array}$ & $\begin{array}{l}\text { Streptococcus pneumoniae } \\
\text { and Neisseria meningitidis }\end{array}$ & $\begin{array}{l}\text { Third or fourth generation } \\
\text { cephalosporin plus } \\
\text { vancomycin }\end{array}$ \\
\hline Otitis, mastoiditis, sinusitis & $\begin{array}{l}\text { Streptococci spp., gram- } \\
\text { negative anaerobes } \\
\text { (Bacteroides sp., } \\
\text { Fusobacterium sp.), S. aureus, } \\
\text { Haemophilus sp., } \\
\text { Enterobacteriaceae }\end{array}$ & $\begin{array}{l}\text { Third or fourth generation } \\
\text { cephalosporin plus } \\
\text { vancomycin plus } \\
\text { metronidazole }\end{array}$ \\
\hline $\begin{array}{l}\text { Adults over the age of } 55 \\
\text { and those with chronic illness }\end{array}$ & $\begin{array}{l}\text { Streptococcus pneumoniae, } \\
\text { gram-negative bacilli, } \\
\text { Neisseria meningitidis, Listeria } \\
\text { monocytogenes, Haemophilus } \\
\text { influenzae }\end{array}$ & $\begin{array}{l}\text { Third or fourth generation } \\
\text { cephalosporin plus } \\
\text { vancomycin plus ampiciilin }\end{array}$ \\
\hline Endocarditis & $\begin{array}{l}\text { viridans streptococci, S. } \\
\text { aureus, Streptococcus bovis, } \\
\text { HACEK group, Enterococci }\end{array}$ & $\begin{array}{l}\text { Third or fourth generation } \\
\text { cephalosporin plus } \\
\text { vancomycin }\end{array}$ \\
\hline
\end{tabular}




\begin{tabular}{|l|l|l|}
\hline Immunosuppressed & $\begin{array}{l}\text { Streptococcus pneumoniae, } \\
\text { Listeria monocytogenes, } \\
\text { Haemophilus influenzae }\end{array}$ & $\begin{array}{l}\text { Third or fourth generation } \\
\text { cephalosporin plus } \\
\text { vancomycin plus ampicillin }\end{array}$ \\
\hline Postneurosurgical & $\begin{array}{l}\text { Staphylococci, gram-negative } \\
\text { bacilli }\end{array}$ & $\begin{array}{l}\text { Vancomycin plus meropenem } \\
\text { or vancomycin plus } \\
\text { ceftazidime }\end{array}$ \\
\hline Intraventricular device & Staphylococci, gram-negative & Vancomycin plus meropenem \\
& bacilli, anaerobes & or vancomycin plus \\
& & ceftazidime plus \\
& & metronidazole \\
\hline
\end{tabular}

The HACEK group is Haemophilus sp., Actinobacillus actinomycetemcomitans, Cardiobacterium hominis, Eikenella corrodens, and Kingella kingae.

Table 2. Recommended doses for the antibiotics commonly used in the treatment of bacterial central nervous system infections

\begin{tabular}{|l|l|}
\hline Antibiotic agent & $\begin{array}{l}\text { Total daily dosage (dosing interval in } \\
\text { hours) }\end{array}$ \\
\hline Ampicillin & Infants and children: $300 \mathrm{mg} / \mathrm{kg} / \mathrm{d}$ (q6h) \\
& Adult: $12 \mathrm{~g} / \mathrm{d}$ (q4-6h) \\
\hline Cefepime & Infants and children: $150 \mathrm{mg} / \mathrm{kg} / \mathrm{d}$ (q8h) \\
& Adult: $6 \mathrm{~g} / \mathrm{d}$ (q8h) \\
\hline Cefotaxime & Infants and children: $225-300 \mathrm{mg} / \mathrm{kg} / \mathrm{d}$ (q6-8h) \\
& Adult: $8-12 \mathrm{~g} / \mathrm{d}$ (q4-6h) \\
\hline
\end{tabular}




\begin{tabular}{|c|c|}
\hline Ceftriaxone & $\begin{array}{l}\text { Infants and children: } 80-100 \text { mg/kg/d (q12h) } \\
\text { Adult: } 4 \text { g/d (q12h) }\end{array}$ \\
\hline Gentamicin & $\begin{array}{l}\text { Infants and children: } 7.5 \mathrm{mg} / \mathrm{kg} / \mathrm{d} \text { (q8h) } \\
\text { Adult: } 5 \mathrm{mg} / \mathrm{kg} / \mathrm{d}(\mathrm{q} 8 \mathrm{~h})\end{array}$ \\
\hline Meropenem & $\begin{array}{l}\text { Infants and children: } 120 \mathrm{mg} / \mathrm{kg} / \mathrm{d} \text { (q8h) } \\
\text { Adult: } 6 \mathrm{~g} / \mathrm{d}(\mathrm{q} 8 \mathrm{~h})\end{array}$ \\
\hline Metronidazole & $\begin{array}{l}\text { Infants and children: } 30 \mathrm{mg} / \mathrm{kg} / \mathrm{d} \text { (q6h) } \\
\text { Adult dose: } 2000 \mathrm{mg} / \mathrm{day}(\mathrm{q} 6 \mathrm{~h})\end{array}$ \\
\hline Nafcillin & $\begin{array}{l}\text { Infants and children: } 200 \mathrm{mg} / \mathrm{kg} / \mathrm{d} \text { (q6h) } \\
\text { Adult: } 9-12 \mathrm{~g} / \mathrm{d}(\mathrm{q} 4 \mathrm{~h})\end{array}$ \\
\hline Penicillin G & $\begin{array}{l}\text { Infants and children: } 0.3 \mathrm{mU} / \mathrm{kg} / \mathrm{d} \text { (q4-6h) } \\
\text { Adult: } 24 \text { million units/d (q4-6h) }\end{array}$ \\
\hline Rifampin & $\begin{array}{l}\text { Infants and children: } 10-20 \mathrm{mg} / \mathrm{kg} / \mathrm{d}(\mathrm{q} 12-24 \mathrm{~h}) \\
\text { Adults: } 600-1200 \mathrm{mg} / \mathrm{d}(\mathrm{q} 12 \mathrm{~h})\end{array}$ \\
\hline Vancomycin* & $\begin{array}{l}\text { Infants and children: } 60 \mathrm{mg} / \mathrm{kg} / \mathrm{d} \text { (q6h) } \\
\text { Adults: } 45-60 \mathrm{mg} / \mathrm{kg} / \mathrm{d}(\mathrm{q} 6-12 \mathrm{~h})\end{array}$ \\
\hline Chemoprophylaxis & Rifampin $600 \mathrm{mg}$ twice daily for two days or \\
\hline Neisseria meningitidis & Ceftriaxone $250 \mathrm{mg}$ intramuscular or \\
\hline
\end{tabular}


\begin{tabular}{|l|l|}
\hline & \\
\hline
\end{tabular}

*Intraventricular vancomycin administration: children $10 \mathrm{mg} / \mathrm{d}$, adults $20 \mathrm{mg} / \mathrm{d}$

\section{Etiological organism}

Despite the progress that has been made with vaccination, the most common causative organisms of community-acquired bacterial meningitis are Streptococcus pneumoniae and Neisseria meningitides. The tetravalent meningococcal vaccine that is used to vaccinate adolescents in the United States, contains serogroups A, C, W-135 and Y. The vaccine does not contain serotype $B$, which is the causative organism of one third of cases of meningococcal disease in industrialized countries. ${ }^{8}$ The pneumococcal vaccines decrease the incidence of acute otitis media and pneumonia, but is not a "meningitis vaccine."

Predisposing and associated conditions help predict the meningeal pathogen. In the patient with pneumonia, Streptococcus pneumoniae is a likely meningeal pathogen. When meningitis is suspected in a patient with a recent history of otitis, sinusitis or mastoiditis, the etiological organisms are Streptococci spp. (including S. pneumoniae), gram-negative anaerobes, S. aureus, Haemophilus sp., or Enterobacteriaceae. The most common causative organisms of bacterial meningitis in the patient that has had a neurosurgical procedure are staphylococci, gram-negative bacilli and anaerobes. It is important to recognize when an anaerobe may be the meningeal pathogen as that possibility necessitates the addition of metronidazole to the empiric regimen.

Include Listeria monocytogenes as a possible meningeal pathogen in the pregnant patient, adults over the age of 55, and in individuals with impaired cell-mediated immunity due to chronic illness, organ transplantation, AIDS, malignancy or immunosuppressive therapy. This is important because these predisposing factors necessitate the addition of ampicillin to the empiric antimicrobial regimen. In general, avoid the use of gentamicin whenever possible, but gentamicin is added to the empiric antimicrobial regimen in critically ill patients suspected of having Listeria monocytogenes meningitis.

\section{Diagnostic studies}

By the time the neurologist is consulted by the Emergency Department, the patient has had a peripheral white blood cell count and a CT scan performed. Blood cultures, a C-reactive protein and a serum procalcitonin should be obtained. A normal C-reactive protein has a high negative predictive value in the diagnosis of bacterial meningitis. ${ }^{5}$ An elevated serum procalcitonin concentration occurs in severe bacterial infections. The serum procalcitonin is an additional helpful test in differentiating bacterial meningitis from viral meningitis when the CSF Gram's stain is negative.

The gold standard for the diagnosis of bacterial meningitis is, of course, analysis of the cerebrospinal fluid. The neurologist is critical to the care of the patient with meningitis because few physicians other than neurologists have the skills to perform lumbar punctures, even fewer can 
manipulate a manometer to obtain an opening pressure or have the knowledge to send the critical tests on spinal fluid. In addition, the eradication of the meningeal pathogen is the easy part, it is the recognition and management of the neurological complications that is much more difficult, but more on that later.

Table 3 is the list of diagnostic tests to send on cerebrospinal fluid (CSF). The classic CSF abnormalities in bacterial meningitis are the following: 1) increased opening pressure. It is always a good idea to put the additional extension piece on the manometer, as opening pressures as high as or higher than $500 \mathrm{~mm} \mathrm{H}_{2} \mathrm{O}$ are not unusual. 2) A pleocytosis of polymorphonuclear leukocytes. Cerebrospinal fluid should be handled with care and examined promptly for white blood cells after it is obtained. If the CSF is allowed to sit around for hours before it is examined, allowed to get warm or is launched through a hospital tube system, the white blood cell count will be erroneously low. 3) A glucose concentration of less than $40 \mathrm{mg} / \mathrm{dL}$. It is not unusual to have a CSF glucose concentration in the single digits. Always obtain a serum glucose concentration immediately before performing a lumbar puncture when bacterial meningitis is a possibility as hyperglycemia increases the CSF glucose concentration. A normal CSF:serum ratio is 0.6. A CSF:serum ratio of less than 0.40 is highly predictive of bacterial meningitis. In general, a decreased CSF glucose concentration is evidence of both a potentially treatable and potentially fatal central nervous system (CNS) infection (i.e. bacterial, fungal, tuberculous or carcinomatous meningitis). 4) An elevated protein concentration. Any process that increases the permeability of the blood brain barrier increases the CSF protein concentration. 5) Gram's stain is positive in identifying the organism in $60-90 \%$ of cases of bacterial meningitis, but the probability of a positive Gram's stain is dependent on the number of organisms present. The results of a Gram's stain are usually available in four hours. 6) The CSF culture result is not only critical for the identification of the meningeal pathogen, but also for antimicrobial sensitivity testing. 7) On the initial CSF analysis, in addition to the presence or absence of a pleocytosis, the identification of the predominant cell type being either polymorphonuclear leukocytes or lymphocytes, the presence or absence of a decreased glucose concentration and the results of the Gram's stain, there are three polymerase chain reaction (PCR) assays that are important in the initial diagnostic stage. These are the 16S rRNA conserved sequence broad based bacterial PCR, the reverse transcriptase (RT) PCR for enteroviruses and the herpes simplex virus-2 (HSV-2) PCR. The results for the $16 \mathrm{~S}$ rRNA bacterial PCR take 48 hours or longer to be reported, and typically by the time this result is available the organism has been definitively identified by CSF culture. This PCR is expected to be most helpful in those patient's with a negative Gram's stain and culture as the result of pretreatment with antibiotics for their predisposing condition of pneumonia, otitis, sinusitis, etc. Fortunately the RT-PCR for enteroviruses is reported in four hours. As enteroviruses are the most common cause of viral meningitis, a positive CSF RT-PCR for enteroviruses is very helpful in management decisions. 7) The CSF lactate concentration is in general nonspecific and only recommended in the diagnosis of bacterial meningitis in the postoperative neurosurgical patient. A CSF lactate concentration $\geq 4.0 \mathrm{mmol} / \mathrm{L}$ is positive. 8) The latex agglutination test was a great test that is no longer available. 
Table 3 Cerebrospinal fluid diagnostic studies for meningitis

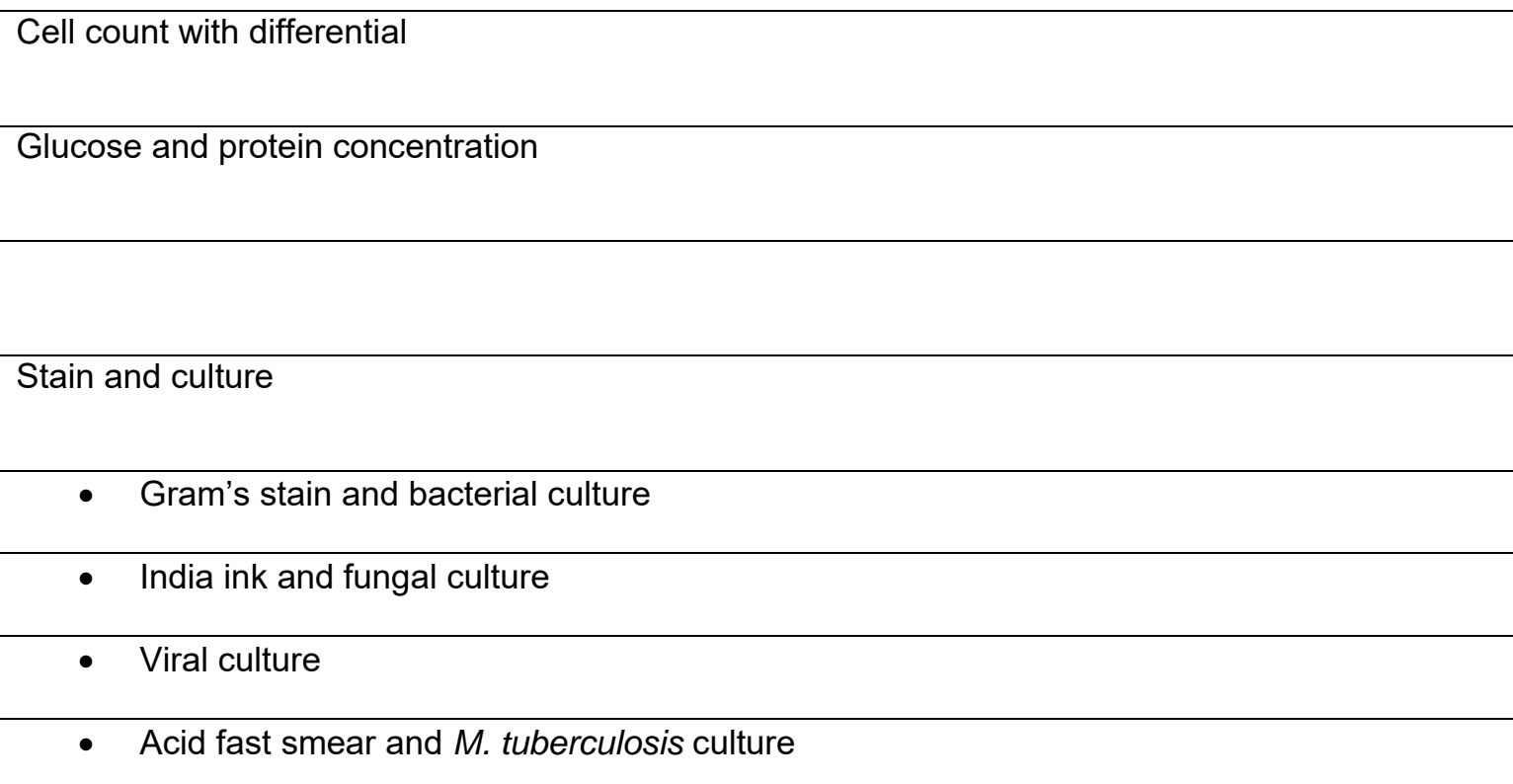

Antigens/Antibodies if fungal meningitis is in the differential

- Cryptococcal polysaccharide antigen

- Histoplasma polysaccharide antigen

- C. immitis complement fixation antibody

Polymerase chain reaction

- $\quad$ Broad range bacterial PCR (16S ribosomal DNA)

- $\quad$ Specific meningeal pathogen PCR

- Reverse transcriptase PCR for enteroviruses

- $\quad$ PCR for herpes simplex virus type 1 and 2

- $\quad$ PCR for West Nile virus

- $\quad$ PCR for Epstein Barr virus 
- $\quad$ PCR for varicella zoster virus

- $\quad$ PCR for M. tuberculosis

- $\quad$ PCR for HIV RNA

Antibodies

- Herpes simplex virus (serum and CSF IgG to calculate antibody ratio)

- Varicella zoster virus IgM, and IgG antibody index

- $\quad$ Arthropod-borne viruses (West Nile virus IgM)

- Borrelia burgdorferi antibody index

\section{Differential diagnosis}

In the patient with a clinical presentation of fever, headache and stiff neck, the leading disease in the differential diagnosis is viral meningitis. Patients with viral meningitis are awake and alert. They are often sitting on the examination table complaining about the severity of their headache. Patients with viral meningitis do not have an altered level of consciousness, seizures or focal neurological deficits. Patients with bacterial meningitis have a progressive decrease in the level of consciousness from lethargy to stupor to obtundation to coma. They are not sitting up, but rather, they are lying down. Tuberculous meningitis may also present with the apoplectic onset of fever and headache, and thus the recommendation that CSF analysis include a PCR for Mycobacterium tuberculosis and acid fast smear and M. tuberculosis culture. A common term used instead of PCR, especially for Mycobacterium tuberculosis, is nucleic acid amplification test, the abbreviation of which is NAAT. Fungal meningitis tends to have a more insidious onset over several weeks with headache, fever, cranial nerve palsies and an altered level of consciousness.

The list of medications that can cause drug-induced meningitis is ever increasing due to the increasing number of immunomodulating agents. Some of the better known culprits are the penicillins, cephalosporins, sulfonamides, trimethoprim, IVIg, azathioprine, cytosine arabinoside, nonsteroidal anti-inflammatory agents, etc. The clinical presentation includes fever, headache, stiff neck, lethargy, confusion, seizures and coma. Spinal fluid analysis may demonstrate an increased opening pressure, a pleocytosis of polymorphonuclear leukocytes and a decreased glucose concentration. There may be diffuse enhancement of the meninges post the administration of 
contrast on CT or MRI. Cerebrospinal fluid Gram's stain and culture are negative, and the symptoms resolve promptly when the offending medication is discontinued. ${ }^{9}$

Herpes simplex virus encephalitis is in the differential diagnosis in any patient with fever and headache. In the majority of patients with herpes simplex virus encephalitis, on fluid attenuated inversion recovery (FLAIR) and diffusion-weighted MRI sequences within 48 hours of symptom onset, there will be a hyperintensity in the inferior and medial temporal lobe. If the initial CSF PCR for HSV-1 is negative, and the suspicion for herpes simplex virus encephalitis is strong, repeat the spinal fluid analysis. A false negative PCR for HSV-1 may occur in the first 72 hours of symptom onset.

An infectious intracranial mass lesion will be readily visualized on neuroimaging. A subarachnoid hemorrhage may also present like bacterial meningitis with the sudden onset of headache and stiff neck. Neuroimaging and spinal fluid analysis will demonstrate hemorrhage prompting CT angiography for an intracranial aneurysm.

\section{Case \#1}

A 19 year old freshman at Princeton University present to the Emergency Room complaining of chills, headache and vomiting for the last 12 hours. He has recently been treated with amoxicillin for an otitis media. On examination, his temperature is $38.7^{\circ} \mathrm{C}$, he has photophobia and is increasingly lethargic. You obtain blood cultures and treat him with dexamethasone $0.15 \mathrm{mg} / \mathrm{kg}$, ceftriaxone $2 \mathrm{gm}$, vancomycin $15 \mathrm{mg} / \mathrm{kg}$, metronidazole $500 \mathrm{mg}$ and acyclovir $10 \mathrm{mg} / \mathrm{kg}$. Spinal fluid analysis demonstrates an opening pressure of $480 \mathrm{~mm} \mathrm{H}_{2} \mathrm{O}, 868 \mathrm{WBCs} / \mathrm{mm}^{3}$, with a predominance of polymorphonuclear leukocytes, a glucose concentration of $6 \mathrm{mg} / \mathrm{dL}$, and a protein concentration of $480 \mathrm{mg} / \mathrm{dL}$. Cerebrospinal fluid Gram's stain demonstrates a gram-negative organism and culture grows Fusobacterium necrophorum.

Comment: Neisseria meningitides serotype B is a good consideration in a college age patient, especially one that attends Princeton University where they had the recent outbreak of meningitis due to this organism. The predisposing factor of otitis media puts him at risk for meningitis due to a gram-negative anaerobe; thus, the addition of metronidazole to the empiric regimen was important.

\section{Management}

The management of bacterial meningitis includes the eradication of the meningeal pathogen with antimicrobial therapy as well as the prevention, as much as possible, and the treatment of the acute complications of this infection. The acute complications of bacterial meningitis are increased intracranial pressure, cerebral edema, coma, ischemic and hemorrhagic cerebrovascular disease, venous sinus thrombosis, cranial nerve palsies and vestibulocochlear involvement.

Empiric antimicrobial therapy is modified once the meningeal pathogen has been identified and results of antimicrobial sensitivity testing are available. Unfortunately, it is both the multiplication of the bacterial organisms as well as the lysis of bacteria by bactericidal antibiotics with the release of bacterial cell wall components that initiates the cascade that leads to the neurological complications. The release of bacterial cell wall components leads to the production of 
inflammatory cytokines and chemokines by monocytes and macrophages and brain astrocytes and microglial cells (CNS-macrophage-equivalent cells). The inflammatory cytokines are the endogenous host mediators of inflammation and are directly responsible for altered blood-brain barrier permeability, decreased cerebral blood flow, the purulent exudate in the subarachnoid space, and the production of excitatory amino acids and reactive oxygen and nitrogen species. The neurological complications that occur as a result of this are vasogenic, interstitial and cytotoxic edema, ischemic and hemorrhagic stroke, venous sinus thrombosis, cranial nerve palsies, seizures, increased intracranial pressure and coma.

Armed with this understanding, the obvious intervention to prevent the pathophysiological consequences and resultant neurological complications from inflammatory cytokines is to prevent the production of the inflammatory cytokines. Thus the interest in decades now in dexamethasone therapy. Investigators using experimental models of meningitis ${ }^{10-12}$ demonstrated dexamethasone inhibited the synthesis of the inflammatory cytokines, reduced meningeal inflammation, decreased cerebral edema and intracranial pressure and stabilized the blood brain barrier (decreasing vasogenic edema and the leakage of serum proteins and the formation of the purulent exudate in the subarachnoid space). The original clinical trials on dexamethasone in bacterial meningitis were done by Lebel et al.13 in Dallas, and Odio et al. ${ }^{14}$ in Costa Rica. Lebel et al. ${ }^{13}$ conducted two consecutive prospective double-blind placebo-controlled trials in 200 infants and children and demonstrated a significantly reduced frequency of moderate, severe or profound bilateral sensorineural hearing loss in the patients who received dexamethasone. Odio et al. ${ }^{14}$ conducted a placebo-controlled double blind trial of dexamethasone therapy in 101 infants and children and demonstrated that neurologic sequelae occurred significantly more often in the patients who were given placebo. These studies led to the recommendation by the American Academy of Pediatrics that the use of dexamethasone be considered in infants and children 2 months of age and older with proven or suspected bacterial meningitis and that the initial does of dexamethasone be given with the initial dose of antimicrobial therapy. ${ }^{15}$

The initial reluctance to use dexamethasone in all patients was that in the landmark studies (above) the majority of patient were infants and children and they had meningitis due to Haemophilus influenzae type $\mathrm{b}$. The efficacy of dexamethasone had yet to be proven in adults, or in meningitis due to Streptococcus pneumoniae or Neisseria meningitidis. The experimental models of meningitis suggested that dexamethasone should be efficacious in meningitis due to either a gram-positive or a gram-negative organism as each had a component/s of their cell wall that stimulated the production of the inflammatory cytokines.

In 2002, de Gans et al. ${ }^{16}$ published the results of their prospective, randomized , double-blind, multicenter trial of dexamethasone in 301 adults with acute bacterial meningitis. Streptococcus pneumoniae was the causative organism in 58 of the patients in the dexamethasone group and 50 in the placebo group. $26 \%$ of the patients with pneumococcal meningitis in the dexamethasone group had an unfavorable outcome compared with $52 \%$ in the placebo group. $14 \%$ of the patients with pneumococcal meningitis who received dexamethasone died compared to $34 \%$ of those who received placebo. After the initiation of nationwide dexamethasone therapy in adults with 
pneumococcal meningitis in the Netherlands, there was a decline in the fatality rate from $30 \%$ to $20 \%{ }^{7}$

Both the Infectious Diseases Society of America Practice Guidelines for the Management of Bacterial Meningitis ${ }^{5}$ and the European Federation of Neurological Societies Guideline on the Management of Community-Acquired Bacterial Meningitis ${ }^{6}$ recommend the use of dexamethasone in adults with suspected or proven pneumococcal meningitis. The Infectious Diseases Society of America Practice Guidelines also acknowledged that "some authorities would initiate dexamethasone in all adults with suspected bacterial meningitis because the etiology of meningitis is not always ascertained at initial evaluation. ${ }^{5}$ In fact a recent study demonstrated a favorable trend toward reduced rates of death and hearing loss and no evidence that dexamethasone was harmful in patients with meningococcal meningitis. ${ }^{7}$ The European Federation of Neurological Societies Task Force 6 also recommends that dexamethasone be administered to children with suspected pneumococcal or Haemophilus influenzae type b meningitis.

The American Academy of Pediatrics, the Infectious Diseases Society of America and the European Federation of Neurological Societies all agree that the dose of dexamethasone is $0.15 \mathrm{mg} / \mathrm{kg}$ every six hours for 2-4 days, and that the initial dose of dexamethasone should be given either before or with the initial dose of antimicrobial therapy.

Neurologists are often asked if dexamethasone should be started four days or more after the patient has been treated with antibiotic therapy and is getting progressively worse. The answer is the evidence supports the use of dexamethasone at the initiation of therapy and for the first four days. After the inflammatory cytokines have initiated the cascade, therapy should be directed at the specific management of increased intracranial pressure, seizures, stroke, etc.

Cerebral edema and increased intracranial pressure in bacterial meningitis is managed as it is when it occurs as a complication of other central nervous system disorders with elevation of the head of the bed, hyperventilation and mannitol. Seizures are often the result of cerebrovascular complications and are treated accordingly.

Patients that develop neurological complications during the acute phase of bacterial meningitis are at risk for permanent neurological sequelae, including cognitive impairment, hearing loss, seizure disorders, etc.

\section{Spinal epidural abscess}

The incidence of spinal epidural abscess has increased for two reasons: 1) Staphylococcus aureus is the most common causative organism, and infections due to this organism have increased, 2) diabetes is the single most important risk factor for the development of a spinal epidural abscess. Neurologists are often consulted for "weakness," making the timely recognition and diagnosis of a spinal epidural abscess an entity that "we own." We also care for these patients long term, and as such have the best understanding of prognosis.

A spinal epidural abscess has a classic presentation as described by Heusner in $1948 .{ }^{18}$ 
- Back pain at the level of infection. In addition, fever may be present, but is not universally present.

- Pain in a radicular distribution in the extremities or an intercostal thoracic dermatomal distribution.

- Paresis, loss of sensation below the level of the lesion and loss of bowel and bladder control.

- Paralysis.

\section{Etiological organism}

A spinal epidural abscess develops by one of the following mechanisms: 1) as a result of hematogenous dissemination from a remote site of infection during the course of bacteremia; 2 ) from a contiguous site of infection (vertebral osteomyelitis/discitis, decubitus ulcers, infected abdominal wounds, soft tissue paravertebral abscesses,); 3) trauma, and 4) direct inoculation during spinal instrumentation or epidural analgesia. Staphylococcus aureus is the most common causative organism followed by gram-negative bacilli. Empiric antibiotic therapy should include a combination of vancomycin and a third or fourth generation cephalosporin.

\section{Differential diagnosis}

The differential diagnosis is defined by the neurological examination, specifically the extent and tempo of the development of appendicular weakness, the presence or absence of a sensory level, and the presence or absence of bowel and bladder involvement. Fever and back pain without signs of spinal root or cord compression may be due to osteomyelitis and discitis. The two most common diseases in the differential diagnosis of spinal epidural abscess are transverse myelitis and GuillianBarre syndrome. The clinical presentation of transverse myelitis is that of back pain followed by lower extremity weakness and bowel and bladder dysfunction. Transverse myelitis affecting the cervical cord presents with back pain and upper extremity weakness. The findings on neurological examination are the same as those with a spinal epidural abscess and include appendicular weakness, a well-defined sensory level, hypotonia and absent or decreased muscle stretch reflexes. The Guillain-Barre syndrome presents as an ascending weakness with loss of the muscle stretch reflexes. Urinary retention may develop in the course of the illness as a symptom of autonomic dysfunction, but is not a typical feature of the acute presentation.

Non-neurologists often want to image the entire neuroaxis in a patient with weakness, but the length of time it takes to perform such an extensive MRI delays getting the MRI. It is critical to localize the lesion by the findings on the neurological examination and focus the imaging on the predicted area of the spinal epidural abscess as well as a few levels above and below that.

\section{Case \#2}

A 52 year old is admitted to the hospital complaining of abdominal pain, slowly progressive weakness in his extremities associated with neck pain and dysphagia. Beginning two weeks prior to hospitalization, he noted difficulty walking followed by difficulty with the strength in his left right upper extremity. At the time of admission, he was catheterized and 2 liters of urine were removed. He has had an indwelling catheter since admission. His complaints of weakness were attributed to 
his poor oral intake and deconditioning. He was evaluated by GI, who performed esophagogastroduodenoscopy, which was normal. ENT also evaluated the patient and found no abnormalities in his throat. On hospital day \#3, he develops a fever and a CBC demonstrates a neutrophilic pleocytosis. He is treated for an Escherichia coli urinary tract infection. Neurology is consulted when he develops weakness in his right upper extremity. On neurological examination, he has bilateral lower extremity plegia, asymmetric upper extremity hypotonic paresis and a C2 sensory level. A STAT MRI of the cervical spine is obtained (Figure 1). He has a C3 epidural abscess due to a paravertebral abscess. He is taken to the OR for emergent decompression and drainage of the abscess. Gram's stain of the purulent material obtained from C2 reveals gram-negative bacilli and culture grows E.coli. The neurosurgeon notes there is no pulsation of the cord post decompression, but does remark about the presence of thrombosed epidural veins. The patient does not recover the strength in any of his extremities.

\section{Comment}

The patient's complaint of dysphagia was the focus of evaluation during the first few days of his hospitalization. It was not until he developed weakness under observation in the hospital that neurology was consulted. Despite emergent decompressive surgery, he did not regain function in any of his appendicular musculature. A critical piece to being able to offer an opinion on the prognosis is what the neurosurgeon sees with her eyes on the operative field. This patient had infarction of the spinal cord due to septic thrombophlebitis and is not likely to recover a significant degree of function.

\section{Diagnostic studies}

Routine studies for suspected bacterial infection of the central nervous system include CBC with differential, sed rate, C-reactive protein, serum procalcitonin and blood cultures. It is extremely difficult to obtain an urgent MRI of the entire neuroaxis. The level of the lesion must be determined by the neurological examination to narrow (but not limit) the extent of imaging to be obtained.

\section{Management}

Patients with spinal epidural abscess nearly always go to surgery and the procedure that is done is a decompressive laminectomy at one or more levels with drainage of the abscess. Gram's stain and culture of the purulent material obtained at the time of surgery allows for identification of the infecting organism and modification of the antimicrobial coverage. Antimicrobial sensitivity testing of the bacterial culture is critical to ensure that the organism is sensitive to the antibiotic.

\section{Prognosis}

In order to address the prognosis, the neurosurgeon should answer the following questions: 1) Did the spinal cord pulsate post decompression, and 2) was there evidence of thrombosed arteries or veins? If the neurosurgeon does not address the likely pathophysiology in their operative note, they 
should be asked to do so. An understanding of the pathophysiology of the spinal cord injury from the epidural abscess is critical to predicting the extent of recovery to the degree that that can be predicted.

The neurological deficits from a spinal epidural abscess are due to one of or a combination of the following: 1) compression of the spinal cord, 2) compression of the arterial blood supply, 3) arterial or venous thrombosis, 4) septic thrombophlebitis. When the pathophysiology of the neurological deficits is due to spinal cord compression: "The single most important predictor of the final neurologic outcome is the patient's neurologic status immediately before surgery." 19 Patients who undergo surgery with back pain or back pain and radicular pain are expected to have a good outcome with no neurological deficits. Those that undergo surgery with paresis, are expected to have either no weakness or a lesser degree of weakness postoperatively. Patients who are plegic but operated on within 24 to 36 hours of the development of paralysis are expected to regain some strength in the paralyzed extremities. ${ }^{19}$

Compression of the spinal cord as the mechanism of injury in spinal epidural abscess came from experimental models. Staphylococcus aureus was directly inoculated into the epidural space of rabbits to promote abscess formation. In this model, spinal cord compression from epidural abscess formation at the site of inoculation resulted in paralysis. ${ }^{20}$ When compression is the mechanism of injury, improvement from decompressive surgery can be expected.

When vascular pathology is the mechanism of spinal cord injury in spinal epidural abscess, recovery post surgery is not likely. The vascular pathology may be an arteritis with spinal cord ischemia, an arterial or venous thrombosis with spinal cord ischemia or a thrombophlebitis with hypoxia secondary to obstructed venous drainage of the cord. ${ }^{21}$ Thrombophlebitis of the leptomeningeal vessels and arterial occlusion have been visualized intraoperatively and at autopsy. In these reports, cord compression was not the mechanism of injury.22-23It is also possible that both cord compression and vascular pathology are the mechanism of spinal cord injury in any individual patient.

This is such a devastating disease, and now that the incidence of this disease in increasing, it is important to focus our efforts on both prevention, and treatment. Due to the common complaint of back pain, there is often a delay in the diagnosis of spinal epidural abscess. The presence of fever and focal back pain and tenderness warrants imaging of the symptomatic level of the spine. In the patient with a predisposing condition and thus an increased risk for spinal epidural abscess, such as diabetes or $S$. aureus bacteremia, a complaint of back pain should be handled with the same sense of urgency as a complaint of chest pain. 


\section{References}

1. Durand ML, Calderwood SB, Weber DJ, Miller SI, et al. Acute bacterial meningitis in adults - a review of 493 episodes. N Engl J Med 1993;328:21-28.

2. van de Beek D, de Gans J, Spanjaard L, Weisfelt M, Reitsma JB, Vermeulen M. Clinical features and prognostic factors in adults with bacterial meningitis. $\mathrm{N}$ Engl J Med 2004;351: 1849-59.

3. Thomas KE, Hasbun R, Jekel J, Quagliarello VJ. The diagnostic accuracy of Kernig's sign, Brudzinski's sign, and nuchal rigidity in adults with suspected meningitis. Clin Infect Dis 2002;35: 46-52.

4. Roos KL, van de Beek D. Bacterial meningitis. In: Roos KR, Tunkel AR, editors. Handbook of Clinical Neurology. Edinburgh: Elsevier; 2010. p 51-63.

5. Tunkel AR, Hartman BJ, Kaplan BA, et al. Practice Guidelines for the management of bacterial meningitis. Clin Infect Dis 2004;39:1267-1284.

6. Chaudhuri A, Martin PM, Kennedy PGE, Seaton A, et al. EFNS guideline on the management of community-acquired bacterial meningitis: report of an EFNS Task Force on acute bacterial meningitis in older children and adults. Eur J Neurol 2008:15: 649659.

7. Heckenberg SGB, Brouwer MC, van der Ende A, van de Beek D. Adjunctive dexamethasone in adults with bacterial meningitis. Neurology 2012;79:1563-1569.

8. Tan LKK, Carlone GM, Borrow R. Advances in the development of vaccines against Neisseria meningitidis. N Engl J Med 2001;344:1378-1388.

9. De Marcaida JA, Reik L. Disorders that mimic central nervous system infections. In: Marra CM, ed. Neurologic Clinics;17(4):1999, pgs. 901-941.

10. Mustafa MM, Ramilo O, Olsen KD, et al. Tumor necrosis factor in mediating experimental Haemophilus influenzae type b meningitis. J Clin Invest 1989;84:12531259.

11. Kern JA, Lamb RJ, Reed JC, Daniele RP, Nowell PC. Dexamethasone inhibition of interleukin 1 beta production by human monocytes. J Clin Invest 1988;81:237-244.

12. Tauber MG, Khayam-Bashi H, Sande MA. Effects of ampicillin and corticosteroids on brain water content, cerebrospinal fluid pressure, and cerebrospinal fluid lactate levels in experimental pneumococcal meningitis. J Infect Dis 1985;151:528-534. 
13. Lebel MH, Freij BJ, Syrogiannopoulos GA, et al. Dexamethasone therapy for bacterial meningitis; results of two double-blind, placebo-controlled trials. N Engl J Med 1988;319:964-971.

14. Odio CM, Faingezicht I, Paris M, et al. The beneficial effects of early dexamethasone administration in infants and children with bacterial meningitis. N Engl J Med 1991;324:1525-1531.

15. Committee on Infectious Diseases, American Academy of Pediatrics: Dexamethasone therapy for bacterial meningitis in infants and children. Pediatrics 1990;86:130-133.

16. de Gans J, van de Beek D, For the European Dexamethasone in Adulthood Bacterial Meningitis Study Investigators. Dexamethasone in adults with bacterial meningitis. N Engl J Med 2002;347:1549-1556.

17. Brouwer MC, Heckenberg SGB, de Gans J, Spanjaard L. Nationwide implementation of adjunctive dexamethasone therapy for pneumococcal meningitis. Neurology 2010;75:1533-1539.

18. Heusner AP. Nontuberculous spinal epidural abscess. N Engl J Med 1948;239:845.

19. Darouiche RO. Spinal epidural abscess. N Engl J Med 2006;355:2012-20.

20. Feldenzer JA, McKeever PE, Schaberg DR, Campbell JA, Hoff JT. Experimental spinal epidural abscess: a pathophysiological model in the rabbit. Neurosurgery 1987;20 (6):859-867.

21. Akalan N, Ozgen T. Infection as a cause of spinal cord compression: a review of 36 spinal epidural abscess cases. Acta Neurochir 2000;142(1):17-23.

22. Van de Warrenburg BPC, Wesseling P, Leyten QH, Boerman RH. Myelopathy due to spinal epidural abscess without cord compression: a diagnostic pitfall. Clin Neuropath 2004;23 (3):102-106.

23. Iwasaki M, Yano S, Aoyama T, Hida K, Iwasaki Y. Acute onset intramedullary spinal cord abscess with spinal artery occlusion: a case report and review. Eur Spine J 2011;S294-301. 